\title{
Mineralogical Composition and Structure of Fibrous Anthophyllite: A Case Study from Argentina
}

\author{
Lescano Leticia, Marfil Silvina, Sfragulla Jorge, Bonalumi Aldo, \\ and Maiza Pedro
}

\section{Abstract}

In this work a multimethodological approach is taken, complementing field studies with petrographicmineralogical, compositional and morphological analyses of anthophyllite in the "Coco Solo" mine from the province of Córdoba (Argentina). Fibrous minerals were studied by stereomicroscopy, polarizing light microscopy and SEM. The fibres have positive elongation, straight extinction and slight pleochroism. Thermogravimetric and differential scanning calorimetry (TG/DSC) data allowed the determination of the structural water content and temperature stability. X-ray diffraction was used for the characterization of the mineral fibres before and after heating at $1000{ }^{\circ} \mathrm{C}$ to identify the products of thermal decomposition. The crystal structure determined corresponds to anthophyllite. Finally, morphological analyses on acicular and fibrous phases were conducted. Particles up to $\sim 1 \mu \mathrm{m}$ were analysed by optical microscopy, while particles up to $\sim 0.1 \mu \mathrm{m}$ were examined by SEM. When complemented, these two techniques are useful to characterize the morphologies of the particles.

\section{Keywords}

Asbestos • Anthopyllite - Argentina

\section{Introduction}

In a general sense and from a commercial perspective, the term "asbestos" is defined as a group of six minerals that appear in nature forming bundles of thin and long fibres,

L. Leticia $(\triangle) \cdot M$. Silvina $\cdot$ M. Pedro

Geology Department, Universidad Nacional del Sur, Bahía

Blanca, Argentina

e-mail: leticia.lescano@uns.edu.ar

S. Jorge - B. Aldo

sec. de Minería de la Prov. de Córdoba, Universidad Nacional de Córdoba, Córdoba, Argentina with high tensile strength and flexibility, low thermal and electrical conductivity, high absorbance and thermal stability, and chemical resistance (Gunter et al. 2007). These minerals have been classified as a carcinogen by the U.S. Department of Health and Human Services (HHS), the Environmental Protection Agency (EPA), and the International Agency for Research on Cancer (IARC). Studies have shown that exposure to asbestos may increase the risk of lung cancer and mesothelioma (Yarborough 2006). There are several records related to health problems in miners that work in both underground and open pits, where asbestiform minerals are major or accessory constituents of the ores extracted.

Asbestos is divided into two groups (amphiboles and chrysotile) that form thin and long fibres. They are hazardous due to their morphology. The mineralogical study is essential for assessing their potential impact on human health. Chrysotile fibres have low degrees of aggressiveness as compared to amphiboles. Epidemiological studies show that long and rigid fibres (amphiboles) are more harmful than curly fibres (chrysotile) (Rigarti et al. 2003).

There is scarce information about the potential hazardousness of anthophyllite or tremolite because they have been rarely exploited in pure form. Morphological characterization in itself usually does not constitute a reliable identification criterion (Ross et al. 1984). Hence, microscopic examination methods and other analytical approaches are usually combined. The optical properties of the different types of asbestos fibres, together with information on fibre shapes, enable positive identification of all varieties of asbestos fibres. Their refractive index, colour, pleochroism, birefringence, orientation, etc. cannot always be measured, thus other methods must be employed. TG/DSC data allowed the determination of the structural water content and thermal stability.

In this work a multimethodological approach is taken, complementing field studies with petrographic-mineralogical, compositional and morphological analyses of asbestiform minerals in the "Coco Solo" mine from the province of 
Córdoba (Argentina). The mine object of study was exploited until the end of the 1970s. Although it is currently abandoned, it is important to carry out detailed studies of the deposit to determine the occurrence of asbestiform minerals in the ore and associated with vermiculite, serpentine and talc, currently in operation.

The presence of minerals with asbestiform morphologies and their potential impact on human health have been a subject of study and debate for more than 40 years worldwide (Goodwin 1974; OSHA 1992; Van Gosen et al. 2004). The mineralogical analysis is important to evaluate its health hazard which depends on chemistry, resistance and the most important property: the fibre morphology. But not all asbestos are equally carcinogenic or harmful to human health. Amphibole fibres being the most harmful (Ross et al. 1993).

\section{Materials and Methods}

The geological setting of the Coco Solo mine is composed of an ultramafic lenticular body embedded in amphibolites, $80 \mathrm{~m}$ in length and with variable thickness (between 0.5 and $2 \mathrm{~m}$ ) (Angelleli et al. 1980). Pegmatites appear crosscutting the amphibolite-ultramafic set, generating reaction halos with vermiculite development. The ultramafic talc body is crosscut by fractures filled with asbestos. The fibres crystallize perpendicular and parallel to the subhorizontal and vertical veins respectively. Although the mine is currently closed, detailed studies of the deposit indicate the presence of minerals with asbestiform morphology in the talc ore or associated with vermiculite-rich belts. The fibrous minerals were studied by optical and scanning electron microscopy, TG/DSC (heating at $1000 / 1100{ }^{\circ} \mathrm{C}$ ), and XRD.

\section{Results}

\subsection{Optical and Scanning Electron Microscopy (SEM)}

The fibrous mineral of the Coco Solo mine presents acicular habit, with remarkable crystal development. It can reach from a few microns up to several $\mathrm{cm}$ in length, with a length/width ratio greater than 200 .

The crystals, of asbestiform morphology, are developed along the axis c. Figure 1a shows the acicular crystals in loose grains observed with the optical microscope. They are associated with other fibrous amphiboles, calcite, dolomite and opaque minerals. The fibres are arranged in dense packages concordant with the strike of the mineralized structure as well as amphiboles and carbonates. The fibrous mineral presents brown colour, low pleochroism, high relief, second order interference colour, positive elongation and right extinction. For their optical properties and morphology they are classified as anthopyllite amphibole. Opaque minerals are concentrated mainly in the carbonatic areas. Intense flexure of the crystals, caused by tectonic processes after crystallization, is observed. Discordant and fractured prismatic crystals arranged in an irregular shape are frequently identified (Fig. 1b).

Elongated and acicular fibres were observed by SEM. Abundant smaller fibres are detached from fibre packages as can be seen in Fig. 1c. Figure 1d shows a detail of the morphological characteristics and their distribution.

\subsection{Thermal Analysis (TG/DSC)}

The structural changes of anthophyllite with increasing temperature can be summarized in the following steps: dehydrogenation and/or dehydroxylation accompanied by iron oxidation, structure collapse and crystallization of newly formed crystalline phases, early melting (Bloise et al. 2016).

The DSC diagram (Fig. 2) shows endothermic peaks at 260,574 and $862^{\circ} \mathrm{C}$, and an exothermic peak at $940{ }^{\circ} \mathrm{C}$ attributed to enstatite crystallization. The loss of weight is $4.15 \%$. These results are comparable with the anthophyllite curve shown by Bloise et al. (2016).

The weak peaks at 260 and $546{ }^{\circ} \mathrm{C}$ are attributed to the dehydration and dehydroxylation of mineral impurities in the sample.

\subsection{X-Ray Diffraction (XRD)}

The main reflexions of anthophyllite were identified by XRD and are comparable to ICDD card number 042-0544 (ICDD 1993). The peaks are sharp and with high intensity indicating good crystallinity (Fig. 3a).

The material obtained after the DSC analysis (heated at $1000{ }^{\circ} \mathrm{C}$ ) was also analysed by this method, identifying enstatite (Fig. 3b). This result is similar to that obtained by Bloise et al. (2016).

\section{Conclusions}

The fibrous mineral associated whit talc and vermiculite in the Coco Solo mine (province of Córdoba, Argentina) was determined as anthopyllite.

By optical and SEM microscopy the fibrous mineral presents acicular habits and asbestiform morphology, associated with other fibrous amphiboles, calcite, dolomite and opaque minerals. 

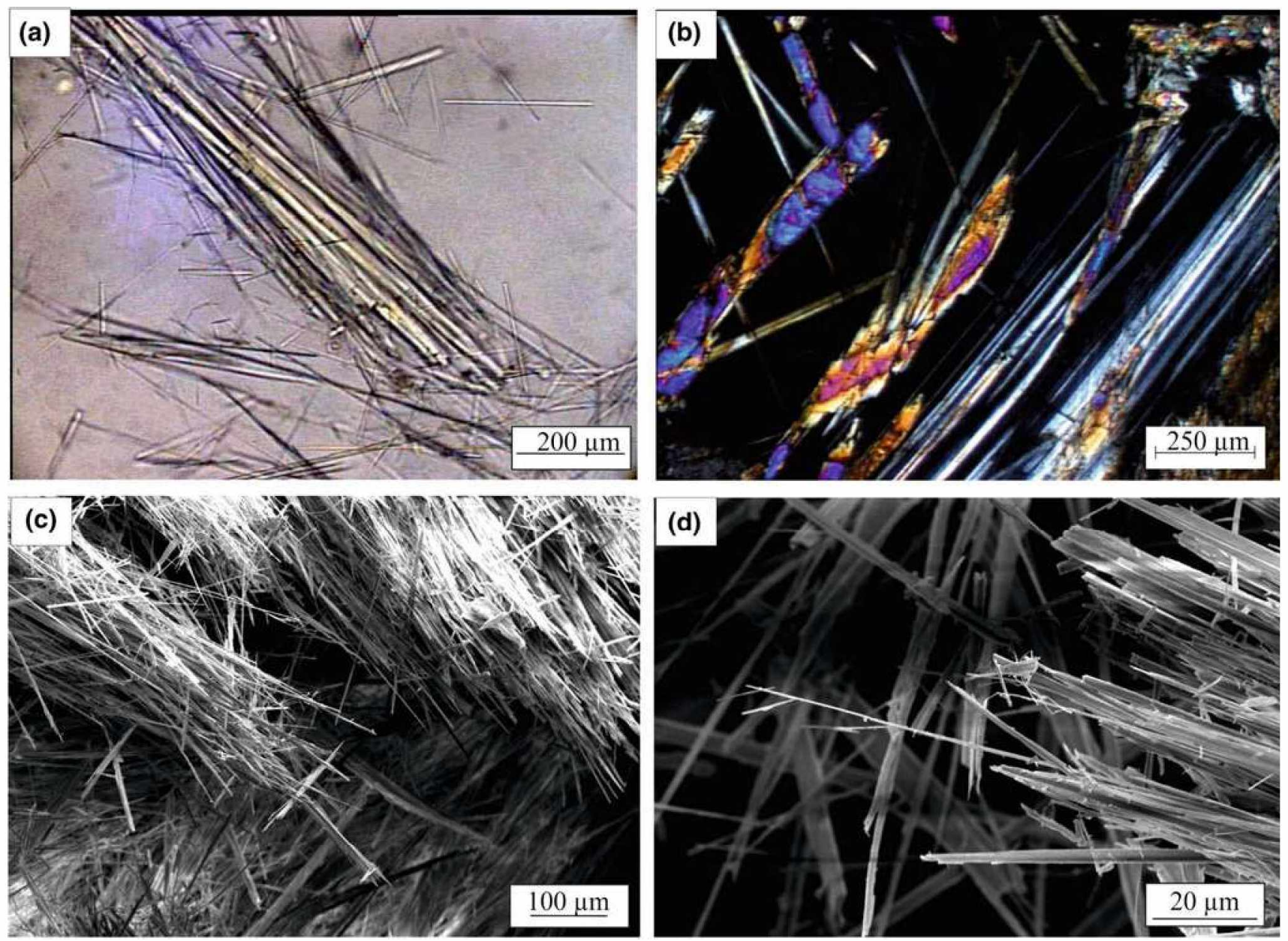

Fig. 1 a Acicular crystals in loose grains. b Anthopyllite in thin section. c, d SEM: morphological characteristics

Fig. 2 DSC-TG of fibrous mineral determined as anthophyllite

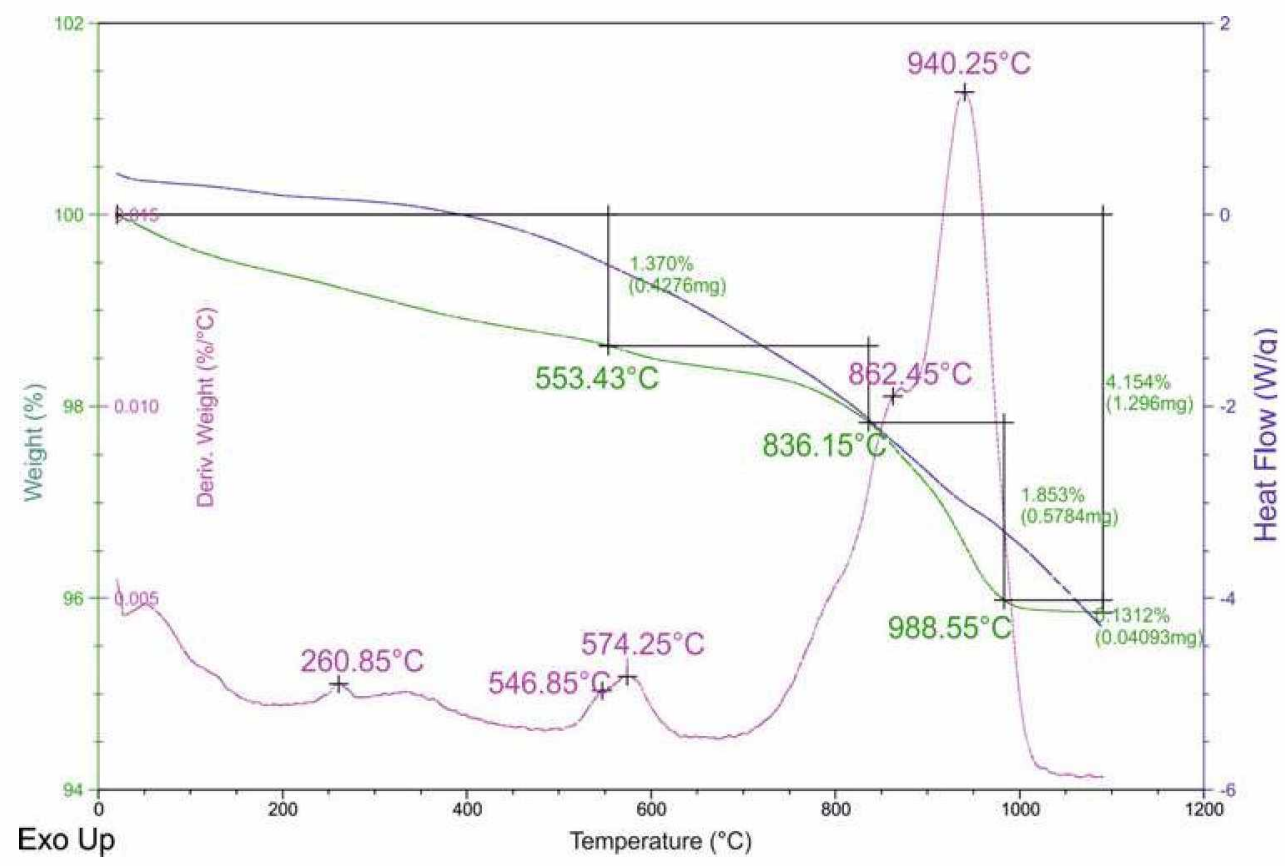



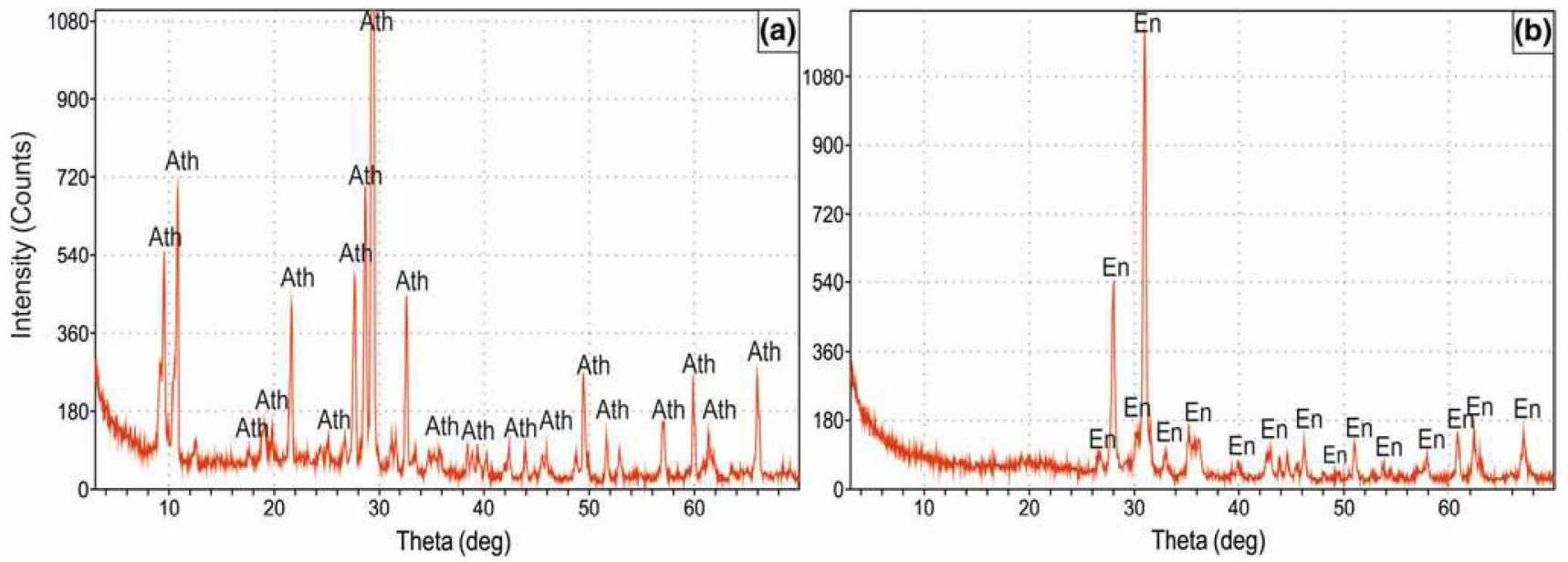

Fig. 3 XRD. a Natural mineral fibres. b Mineral fibres after heating at $1000{ }^{\circ} \mathrm{C}$. Ath: anthophyllite. En: enstatite

By TG, the structural changes of anthophyllite with increasing temperature was determinate. The DSC shows an exothermic peak at $940{ }^{\circ} \mathrm{C}$ attributed to enstatite crystallization.

The main reflexions of anthophyllite were identified by XRD. The material obtained after the DSC analysis was identified as enstatite.

The identified amphibole asbestos may be a potential health hazard during ore mining, transportation, and grinding works.

Acknowledgements Authors thank CIC from the province of Buenos Aires, Geology Department of the Universidad Nacional del Sur and Secretaría de Minería of the province of Córdoba.

\section{References}

Angelelli, V., Schalamuk, I., Fernández, R.: Los yacimientos no metalíferos y rocas de aplicación de la región Centro-Cuyo. Secretaría de Estado de Minería, Anales 19, 1-261 (1980)

Bloise, A., Catalano, M., Barrese, E., Gualtieri, A., Gandolfi, N., Capella, S., Belluso, E.: TG/DSC study of the thermal behaviour of hazardous mineral fibres. J. Therm. Anal. Calorim. 123, 2225-2239 (2016)
Goodwin, A.: Proceedings of the symposium on talc, Washington D.C. Bureau Min. Info. Circular 8639, 102 pp (1974)

Gunter, M., Belluso, E., Mottana, A.: Amphiboles: environmental and health concerns. In: Rosso, J.J. (ed.) Reviews in mineralogy and geochemistry, pp. 453-516. Mineralogical Society of America Geochemical Society, Chantilly (2007)

International Centre for Diffraction Data (ICDD): Mineral powder diffraction file, p. 2389. Databook, Park Lane, Swarthmore. Pennsylvania (1993)

OSHA: Occupational exposure to asbestos, tremolite, anthophyllite and actinolite. Fed. Reg. 57, 24310-24331 (1992). Department of Labor, Occupational Safety and Health Administration, US

Rigarti, C., Aldieri, E., Bergandi, L., Tomatis, M., Fenoglio, I., Costamagna, C.: Long and short fiber amosite asbestos alters at a different extent the redox metabolism in human lung epithelial cells. Toxicol. Appl. Pharmacol. 193, 106-115 (2003)

Ross, M., Kuntze, R., Clifton, R.: A definition for asbestos, pp. 139147. Special Technical Publication 834. American Society for Testing Materials, Philadelphia (1984)

Ross, M., Nolan, R., Langer, A., Cooper, W.: Health effects of mineral dusts other than asbestos. In: Guthrie, G.D., Mossman, B.T. (eds.) Health effects of mineral dusts. Reviews in mineralogy, vol. 28, pp. 361-407. Mining Society of America, Washington DC (1993)

Van Gosen, B., Lowers, H., Sutley, S., Gent, C.: Using the geologic setting of talc deposits as an indicator of amphibole asbestos content. Environ. Geol., 43 pp (2004)

Yarborough, C.: Chrysotile asbestos and mesothelioma. Crit. Rev. Toxicol. 36(2), 165-187 (2006) 